\title{
Editorial Foreword 72.1 (February 2013)
}

\section{Our Cover ANd The Issue AS a Whole}

Our cover contains a photograph of a Balinese funeral ceremony, which is being observed by a crowd made up of locals and international tourists. This photograph, taken by Thea Linke, comes to us courtesy of the authors of "The Bali Bombings Monument: Ceremonial Cosmopolis," an article described below that engages in part with the way that the boundaries between sacred spaces and tourist sites become blurred in Indonesia-as indeed can be the case in many other settings, in Asia and elsewhere.

The issue as a whole, like many JAS numbers, is very diverse when it comes to the types of authors involved and subjects addressed in the "front of the book" articles as well as, of course, the "back of the book" review section. I am pleased to be able to report that authors based on four continents (North America, Europe, Australia, and Asia) contributed articles to this issue; that the issue's opening “Trends” essay touches upon nearly every part of Asia (including countries, such as Turkey, that have strong claims to being seen as "Asian” yet lie beyond the borders of the regions represented in the Association for Asian Studies); that the research articles to follow are the work of scholars in a range of different social science and humanities fields, some of whom analyze texts while others back up their claims with graphs, and some of whom make use of interviews while others root their analysis in documents; and that readers of those articles will encounter data, stories, and individuals with ties to China, Indonesia, Tibet, and Japan.

\section{Trends}

We begin with Jennifer Milioto Matsue's “Stars to the State and Beyond: Globalization, Identity, and Asian Popular Music," a survey of publications by anthropologists and musicologists that opens with an impressionistic evocation of a Tokyo rave. The pages that follow deal with everything from the Vietnamese karaoke industry to the way that "seemingly global sound is localized by youths within socio-cultural and politically transforming China," who have sometimes gotten their first taste of imported rock songs by listening to damaged CDs imported from the West. Exploring various methodological and theoretical issues, including the different ways that studies of popular music have developed in disparate parts of the world, Matsue looks at countries that the JAS regularly addresses and other places as well. The more unusual settings — for this publication — that she 
touches upon include Turkey, which is a bridge between Asia and Europe, but lies outside of the East Asia-South Asia-Southeast Asia range of the Association for Asian Studies, and other parts of the Middle East. She also brings Asian American performances into the story, which is only fitting as one of her concerns, like that of other specialists of popular music, is with the ways that songs, dances, and musical genres move across national borders, taking on new meanings and hybrid forms as they do. The fluidity of popular music and related phenomena has only become clearer since this piece went through copyediting, as between that moment and my writing of this Editorial Foreword, the "Gangnam Style" craze began, starting in South Korea and immediately inspiring parodies and homages everywhere from the People's Republic of China (PRC) to the United States.

\section{Research Articles}

This issue does not have any "Asia Beyond the Headlines" essays, but its first article, with its "ten years on" look at the Bali bombings, one of the first twenty-first-century Asian events to capture the attention of the global media, shares some features with past works in that genre. "The Bali Bombings Monument: Ceremonial Cosmopolis" is a theoretically engaged ethnographic work that, as noted above, is linked to our cover image, albeit quite loosely. It was coauthored by Jeff Lewis, Belinda Lewis, and I Nyoman Darma Putra, an interdisciplinary trio of scholars who are based, respectively, at a global studies center, a school of primary health, and a language and cultures department. The piece looks at the changing meanings of a monument erected a decade ago at the "site of the 2002 Islamist militant attacks in Kuta, Bali," that was intended to serve as "an integrated and culturally harmonious" memorial to the victims of that tragic event. The authors look at the "language wars" that have swirled around the monument, as well as the way it has been integrated into the itineraries of international tourists.

Next come a pair of articles that deal with the contemporary PRC, beginning with "Adapt or Voice: Class, Guanxi, and Protest Propensity in China," a collaboration between two sociologists, one of whom teaches in the United States and the other in Beijing. The participants in this trans-Pacific collaboration, YANG Su and Shizheng Feng, bring together two topics that are often addressed separately by scholars of contemporary China: the importance of guanxi networks (webs of social connections) and patterns of collective contention. The authors show that, while one might expect that people with stronger networks would try to better their situation through means other than protest, this is not always the case. In some settings at least, those with social ties that link them to people in power are actually more rather than less likely to engage in protest. The Journal of Asian Studies, due to its commitment to publishing work that is accessible to scholars in many different disciplines, only rarely runs pieces with a strong quantitative component, but articles such as this one show that it is possible to present numerical data in a manner that can engage a broad spectrum of readers. 
Next up is a piece by Fernanda Pirie, a Tibet specialist who teaches at the Oxford Socio-Legal Studies program. Titled "The Limits of the State: Coercion and Consent in Chinese Tibet," this article, like the Bali monument one, has a "beyond the headlines" aspect to it, for its point of departure is the "protests that swept through Tibet in early 2008 and the subsequent wave of selfimmolations," events that "raise familiar questions about state-society relations and the ways in which China treats its ethnic minorities." Pirie draws on "ethnographic fieldwork among the Tibetan populations of Qinghai and Gansu Provinces" to offer a novel interpretation of how stability is maintained in those regions. This is, she claims, largely the result of creative actions lower-level officials take to "negotiate a form of local order with religious and tribal leaders." These bureaucrats, she notes, often "engage constructively with the expectations of the Tibetans" in the area "about how order should be maintained," rather than simply following in unvarying ways "one size fits all" dictates from the center.

The issue concludes with three forays into Japanese history that focus, respectively, on the first decades of the twentieth century, the Pacific War era, and the 1950s. The initial work in this trio is "Translingual World Order: Language without Culture in Post-Russo-Japanese War Japan," Oxford historian SHO KonISHI's wide-ranging look at the flourishing of Esperanto in a setting often viewed exclusively through a road-to-militarism lens. The author does not ignore the significance of militarist and imperialist ideas in early twentieth-century Japan, but insists that we cannot understand the period fully unless we also consider the significance of a counter-trend, represented by those who championed cooperative, cosmopolitan, and anti-militarist ideas, often associated with Esperanto, rather than belligerent and nationalist ones. He reminds us that in the immediate aftermath of Japan's victory over Russia in 1905, which is often seen as an event that paved the way for the horrors that Japanese troops would inflict on much of Asia several decades later, a leading newspaper could assert that the increasing interest in "the international auxiliary language Esperanto" and naniwa bushi (a popular style of singing) were the two "biggest crazes" of 1906.

Next comes Arizona State University historian Aaron Stephen Moore's “The Yalu River Era of Developing Asia': Japanese Expertise, Colonial Power, and the Construction of Sup'ung Dam," which examines "the construction of one of Japan's largest" wartime "infrastructure projects." Moore sees grand engineering undertakings of this sort as serving as "an important pillar of Japanese imperial rule," which buttressed efforts to present Japan as a legitimate and natural "modernizer of Asia," whose actions could help the region hold its own in a dangerous era in world history. He insists that it is important to "critique, historicize, and denaturalize" the kind of "regime of expertise" championed by defenders of the "Greater East Asian Co-Prosperity Sphere" and also comparable "regimes" at work in our own era.

Closing the issue is another piece rooted in the past but concerned with speaking to contemporary concerns as well by University of Colorado historian Miriam Kingsberg. Titled "Methamphetamine Solution: Drugs and the Reconstruction of Nation in Postwar Japan," it is a compelling exploration of how the 


\section{Editorial Foreword}

Japanese state and specific social groups, ranging from the media establishment to groups of doctors and associations of parents, responded to an addiction crisis in the 1950s. It opens with a discussion of a dramatic event, the murder of a young schoolgirl, that first brought widespread attention to the problem of methamphetamine use in Japan, then moves from there to explore the soul searching and policy moves that followed. Kingsberg focuses on the 1950s, when the drug was nearly eradicated through a series of successful steps taken by governmental and other bodies. But she also contrasts the unusual events of that decade with Japan's "ongoing 'second stimulants epidemic," which began in the 1970s, and reflects "consumption patterns typical of developed nations," and "has proven" much more "resistant to solution" than its post-World War II predecessor.

\section{Forthcoming Articles in JAS 72:2 (May 2013)}

Dialog About Elections in Japan and Korea

David Kang, David Leheny, and Victor Cha

Peter Hessler: Teacher, Archaeologist, Anthropologist, Travel Writer, Master Storyteller Paul A. Cohen

Nationalism, Modernity, and the "Woman Question" in India and China SANJAY SETH

Blazing Pelts and Burning Passions: Nationalism, Cultural Politics, and Spectacular Decommodification in Tibet

EMILY YeH

Beyond Flattery: Legitimating Political Participation in a Ming Living Shrine SARAH SChNEEWIND

Ethnicity, Violence, and Khmer-Vietnamese Relations: The Significance of the Lower Mekong Delta, 1757-1954

Shawn McHale

Convict Carpets: Jails and the Revival of Historic Carpet Design in Colonial India AbBy McGowan

Warlord Colonialism: State Fragmentation and Chinese Rule in Kham, 1911-1949 Joseph D. LAWSON 